\title{
A participatory approach to design monitoring indicators of production diseases in organic dairy farms
}

\author{
J.E. Duval ${ }^{\mathrm{a}, *}$, C. Fourichon ${ }^{\mathrm{a}}$, A. Madouasse ${ }^{\mathrm{a}}$, K. Sjöström $^{\mathrm{b}}$, U. Emanuelson $^{\mathrm{b}}$, N. Bareille ${ }^{\mathrm{a}}$ \\ a BIOEPAR, INRA, Oniris, La Chantrerie, 44307, Nantes, France \\ ${ }^{\mathrm{b}}$ Swedish University of Agricultural Sciences, Department of Clinical Science, Division of Ruminant Medicine and Veterinary Epidemiology, P.O. Box 7054, \\ SE-750 07 Uppsala, Sweden
}

\section{A R T I C L E I N F O}

\section{Article history:}

Received 7 December 2015

Received in revised form 30 March 2016

Accepted 1 April 2016

\section{Keywords:}

Dairy cattle

Herd health

Indicator

Disease prevention

Farmers' decision-making

Extension services

\begin{abstract}
A B S T R A C T
Production diseases have an important negative effect on the health and welfare of dairy cows. Although organic animal production systems aim for high animal health levels, compliance with European organic farming regulations does not guarantee that this is achieved. Herd health and production management (HHPM) programs aim at optimizing herd health by preventing disease and production problems, but as yet they have not been consistently implemented by farmers. We hypothesize that one reason is the mismatch between what scientists propose as indicators for herd health monitoring and what farmers would like to use. Herd health monitoring is a key element in HHPM programs as it permits a regular assessment of the functioning of the different components of the production process. Planned observations or measurements of these components are indispensable for this monitoring. In this study, a participatory approach was used to create an environment in which farmers could adapt the indicators proposed by scientists for monitoring the five main production diseases on dairy cattle farms. The adaptations of the indicators were characterized and the farmers' explanations for the changes made were described. The study was conducted in France and Sweden, which differ in terms of their national organic regulations and existing advisory services. In both countries, twenty certified organic dairy farmers and their animal health management advisors participated in the study. All of the farmers adapted the initial monitoring plan proposed by scientists to specific production and animal health situation on their farm. This resulted in forty unique and farm-specific combinations of indicators for herd health monitoring. All but three farmers intended to monitor five health topics simultaneously using the constructed indicators. The qualitative analysis of the explanations given by farmers for their choices enabled an understanding of farmers' reasons for selecting and adapting indicators. This is valuable information for scientists involved in the design of HHPM programs. Advisors in the field also can benefit from this participatory approach because it transforms monitoring tools provided by scientists into farm-specific tools.
\end{abstract}

(c) 2016 Elsevier B.V. All rights reserved.

\section{Introduction}

Production diseases have an important negative effect on the health and welfare of dairy cows (EFSA, 2009; LeBlanc et al., 2006). European regulations on organic production state that animal health should be promoted by the use of preventive measures, for example by the appropriate choice of breeds, ensuring adequate

\footnotetext{
* Corresponding author.

E-mail addresses: julie.duval@oniris-nantes.fr, julie.duval@gmail.com (J.E. Duval), christine.fourichon@oniris-nantes.fr (C. Fourichon), aurelien.madouasse@oniris-nantes.fr (A. Madouasse), karin.sjostrom@slu.se (K. Sjöström), ulf.emanuelson@slu.se (U. Emanuelson), nathalie.bareille@oniris-nantes.fr (N. Bareille).
}

housing conditions, and the use of alternative therapies in place of chemically synthesized allopathic veterinary treatments when possible (Commission, 2008). Although the production conditions on organic farms aim to promote animal health, the health situations are not always better than on conventional farms (Sundrum, 2001).

A lack of implementation of herd health management practices, and not a lack of knowledge about herd health management, prevents improvements in animal health (LeBlanc et al., 2006). EFSA's Scientific Opinion recommended that research results should be used to design codes of practices and monitoring protocols addressing the major health threats to dairy cattle welfare, such as mastitis, lameness and leg injuries (EFSA, 2012). However, one of the main challenges to reduce or prevent disease is to transform the extensive amount of knowledge generated through research on animal health management into effective and consistently implemented 
practices on each farm (LeBlanc et al., 2006; Tremetsberger and Winckler, 2015). Insufficient compliance by farmers and advisors with management practices proposed in disease control plans is one reason that these plans fail to improve herd health (Bell et al., 2009; Green et al., 2007).

It is conceivable that herd health management practices need to be farmer and farm-specific to ensure farmer compliance. The implementation of management practices relies largely on farmers' intention and perception of their own capacity to do so. The latter can be influenced, for example, by farm-specific constraints and/or a farmer's habits. A farmer's intention to implement management practices can be influenced by multiple factors, such as knowledge of recommended preventive practices and the farmer's attitude towards disease risk (Garforth, 2011). Moreover, management style, defined as the specific combination of a farmer's objectives, motivation, and production environment, is known to influence the implementation of measures to prevent disease (Barkema et al., 1999). Additionally, certain objectives specific to organic dairy farming could influence herd health management in these herds. For example, organic farmers might prioritize maintaining conditions close to those found in nature over securing animal health (Vaarst et al., 2001). Veterinarians are not always aware of the objectives specific to organic dairy farmers or their approach to animal health management (Vaarst et al., 2007). Also, in conventional farming systems, veterinarians are not always aware of farmers' herd health management priorities (Derks et al., 2013b). Thus, to enhance farmer compliance, plans to promote animal health should be designed so that they can be adapted to each farmer's objectives and farm context.

Regular monitoring of herd health is an indispensable component of herd health and production management (HHPM) programs (Brand et al., 2001). Monitoring allows an assessment of whether different elements of the production process are under control and work correctly. This information is obtained by conducting regular planned observations or measurements of these elements (Noordhuizen et al., 2008). The first hurdle is thus to convince farmers to monitor herd health. One hypothesis for poor farmer compliance with HHMP programs is that farmers use different indicators to monitor health than those designed by scientists for HHMP programs. Mathieu et al. (2004) discussed the limits of scientific reasoning in research that aims at changing practices in agriculture; solutions offered by scientists are not always the best solutions in every situation. Moreover, scientists can have other purposes in mind when designing indicators, such as evaluating health at a large population level or for between-farm comparison (EFSA, 2012; Tremetsberger and Winckler, 2015). Indicators relevant for between-farm comparison and within-farm decision-making may differ. Overall, to our knowledge no information is available on farmers' use of indicators for dairy herd health monitoring.

Participatory approaches can be used to design farm-specific tools that are accepted by farmers. The principles of these approaches are to i) include all of the people in the decision-making process whose lives will be affected by the decisions made, ii) acknowledge that local people (in this case, farmers) possess much more knowledge about their own situation (here, their farms) than any outside person could ever obtain, and iii) create an environment to reflect on and analyze information (Whay and Main, 2010). Using a participatory approach creates an opportunity for dialogue between farmers and their animal health advisors on the farmers' goals and objectives (Vaarst et al., 2011). It ensures that the tools are farm-specific, in agreement with the (organic) production system, and based on the farmer's perception of the problems currently on his or her farm. Therefore, we hypothesized that the use of a participatory approach could result in a set of herd health monitoring indicators which would be more farm-specific. This corresponds also with the aim of HHPM programs to support farmers in reaching their farming objectives and in which the farmer is at the center of the decision-making process. These HHPM programs are different from Quality Assurance (QA) programs that set standards aiming at ensuring quality demands from the general public by granting farmers with a license to produce when the standards set are met (Noordhuizen and Wentink, 2001).

The objectives of this study were threefold: (i) to evaluate whether, with the use of a participatory approach, farmers intend to monitor simultaneously major health and welfare indicators associated with production diseases in dairy cattle, (ii) to assess whether the use of a such an approach results in farm-specific indicators to monitor herd health, and (iii) to understand the reasons underlying farmers' selection of indicators.

\section{Material and methods}

\subsection{Approach and general study design}

A survey was performed on a total of 40 organic dairy farms in France and Sweden. The two countries were chosen to represent two different existing contexts regarding the use of health indicators for benchmarking purposes. Scientists designed a prototype of a herd health monitoring tool for the monitoring of five health areas (reproductive health and performance, udder health, calf health, locomotor disorders and metabolic disorders) using 16 indicators. A participatory approach was used to allow farmers and their advisors to adapt the prototype to each farm. The indicators selected by the farmers and advisors from both countries were recorded and analyzed, as well as French farmers' reasons for the adaptations made to the indicators.

\subsection{Selection of organic dairy farmers and advisors}

In France, 20 organic dairy farmers were recruited in the west of the country (the departments of Loire-Atlantique and Morbihan) and in an eastern region (Lorraine). The two geographic areas were chosen to represent different agro-ecological regions and farming systems. The farmers were recruited by local (organic) farmers' organizations. Swedish farmers were recruited by the Swedish coauthors. Invitation letters were sent to 300 organic dairy farms spread over almost half of Sweden and in the area where a relative large proportion of Swedish dairy farms are located. Out of all of the farms which agreed to participate, 20 farms were selected to reflect Swedish farms in structure and herd size.

To be included in the study, the farm had to have been certified for at least one year as an organic dairy farm, and all of the farm owners had to provide their consent with regard to participating in the study and the use of farm data. Participants were informed that the data would be treated anonymously. When several people worked on a farm, the participants were the main decision makers regarding animal health management on the farm.

Prior to the start of the study, the farmers were contacted by telephone to discuss their choice of an animal health advisor. The farmers were allowed to choose anyone they deemed to be appropriate (veterinarian or other). All advisors selected by the farmers agreed to participate.

\subsection{Context of the survey in both countries}

The EU Council Regulation (EC) No 889/2008 does not impose standards with regard to either animal health and welfare levels or monitoring methods (Commission, 2008). In Sweden, there are additional national constraints. All organic dairy farms are certified as organic by the Control Association for Organic Agriculture (Kontrollföreningen för Ekologisk Odling, KRAV). About $77 \%$ of Swedish organic dairy farms deliver milk to the major 
dairies (unpublished data). KRAV standards for animal production follow the EU regulation but have stricter regulations in several areas, including herd health and welfare. This requires systematic recording of health and welfare. KRAV standards compel organic dairy farmers who have chosen to participate in the Swedish Official Milk Recording Scheme (SOMRS) to use the 'Animal Welfare Signals' tool (Signaler Djurvälfärd) for active systematic preventive herd health and welfare management activities. Farmers can obtain a wide range of information from the 'Animal Welfare Signals' tool, from claw trimming reports and economic effects to more specified areas such as reproduction. Often not all information is used, but mainly the overview indicators (Appendix I) (http://www.vxa.se/Radgivning-service/Djurhalsa/Djurvalfard8/ Signaler-DJurvalfard/) (Anonymous, n.d.). If the animal welfare quality standards are not met, organic farmers are obliged to have their herd welfare status assessed by a trained inspector applying animal-based welfare measures. After the assessment, farmers are provided with an action plan and they must meet regularly with their veterinarian over the next two years to follow-up on the preventive measures. About 77\% of the organic dairy farms in Sweden take part in SOMRS. Farmers who have chosen not to participate in SOMRS must nonetheless maintain a recording system to monitor the following welfare indicators: culling rate and cause, mortality in different age groups, total numbers of cases of illness, and claw health (The KRAV Association, 2015). In France, there are no standardized, commonly accepted methods for herd health monitoring, nor are there centralized efforts to develop these. The role of the veterinarian is not described or formally laid down in the regulations. However, this is in line with the European regulation, which does not define the role of veterinarians on organic dairy farms.

\subsection{Design of the participatory approach}

A prototype of a comprehensive herd health monitoring tool for monitoring the main production diseases in dairy cows was designed based on indicators and alert levels identified through a review of the literature and discussions with 10 animal health experts (veterinarians and epidemiologists from the two involved research groups) (Table 1 ). The choice of indicators made by scientists was a compromise between what is considered scientifically to be valid indicators and alert levels for herd health, the herd data available in the field, and what was expected to be an attainable health level in each country. The main aim of these indicators and alert levels was to engage and stimulate discussion between farmers and their advisors on what they wanted to use on their farms.

A meeting was organized on each participating farm with the farmer, his or her advisor, and a researcher (one in France and one in Sweden) to discuss the prototype monitoring tool. The indicators proposed by scientists were discussed by the farmers and advisors and accepted or rejected by the farmers. In the case of rejection, farmers could propose one or more alternative indicators to measure the same health condition. Farmers could also decide not to monitor a certain health topic at all, by choosing no indicator. Additional indicators could also be proposed. An additional indicator was defined as an indicator that measures not the same health condition as the initially proposed indicator but a related condition.

\subsection{Data collection}

Twenty semi-structured discussions were conducted on the participants' farms by the first and fourth author of this article, one working in France, the other in Sweden. In both countries, the interviewers played the role of facilitator, structuring and stimulating the discussion between the farmer and the advisor without sharing or imposing opinions. The farm visits were conducted from midSeptember to the end of December 2014. All of the participants accepted recording of the discussion. The length of the discussions varied from 60 to $150 \mathrm{~min}$.

The visits were conducted in a standardized way in both countries. First, the aims of the visit and of the herd health monitoring plan were explained to the participants. The herd health indicators then were discussed per health topic (udder health, lameness, reproductive failure, metabolic disease and calf health). The farmer was asked first to describe the types of herd health indicators that were already being used on the farm for herd health monitoring. If the farmer did not understand what was meant by the concept of a herd health indicator, or if s/he did not use any indicators, then the researcher presented the proposed herd health indicators. Otherwise, these were presented after the farmer finished explaining his/her existing monitoring methods. Finally, the farmer decided together with his/her advisor which indicators and alert thresholds to retain for herd health monitoring.

Indicators from the prototype accepted by farmers were recorded as well as the alternative and additional indicators proposed. To understand the reasons for the adaptations of the prototype, the discussions were recorded on the French farms and fully transcribed. Budget limitations prevented the same from being done in Sweden.

After the visit, the researcher sent a summary of the visit to both the farmer and the advisor. It included the list of indicators chosen, their corresponding alert thresholds, and the frequency by which indicators would be calculated.

\subsection{Analysis of the indicators used in farmers' herd health monitoring plans}

Firstly, the different herd health indicators retained by the farmers were described. For all health topics, the average number of indicators used was calculated. For each individual indicator, the number of times it was accepted and the number of proposed alternative and additional indicators were described.

Secondly, the alternative and additional indicators proposed by farmers for two health topics, calf health and reproductive health and performance, were compared with those proposed by scientists and classified in categories based on their characteristics. Calf health indicators were selected for two reasons: the highest average number of indicators chosen on Swedish farms concerned calf health, and calf health had never been included in a monitoring plan in France prior to the start of the study. Reproductive health and performance indicators were chosen for analysis because it was the topic for which the highest number of alternative indicators was proposed.

In Table 2, the categories used to classify the differences between the indicators proposed by farmers and those proposed by scientists are presented alongside corresponding examples of the indicators proposed by farmers during the study. This classification was constructed based on the alternative indicators obtained in this study. As one goes down the table, the characteristics become more farm-specific, less suitable for general use, and further away from what was initially proposed. Category $\mathrm{M}$ was added since it became obvious during the analysis that Swedish farmers used animal welfare indicators already recorded in the Swedish 'Animal Welfare Signals' tool.

Thirdly, the discussions on herd health monitoring indicators between farmers and advisors in France were analyzed in detail to gain a better understanding of a farmer's reasoning when designing his/her indicators. For this purpose, across the different interviews, the reasons stated were labeled with key words which were later grouped into larger categories (using Sonal ${ }^{\circledR}$ and Mindmanager ${ }^{\circledR}$ software. 
Table 1

Initial list of indicators to monitor dairy herd health proposed by scientists.

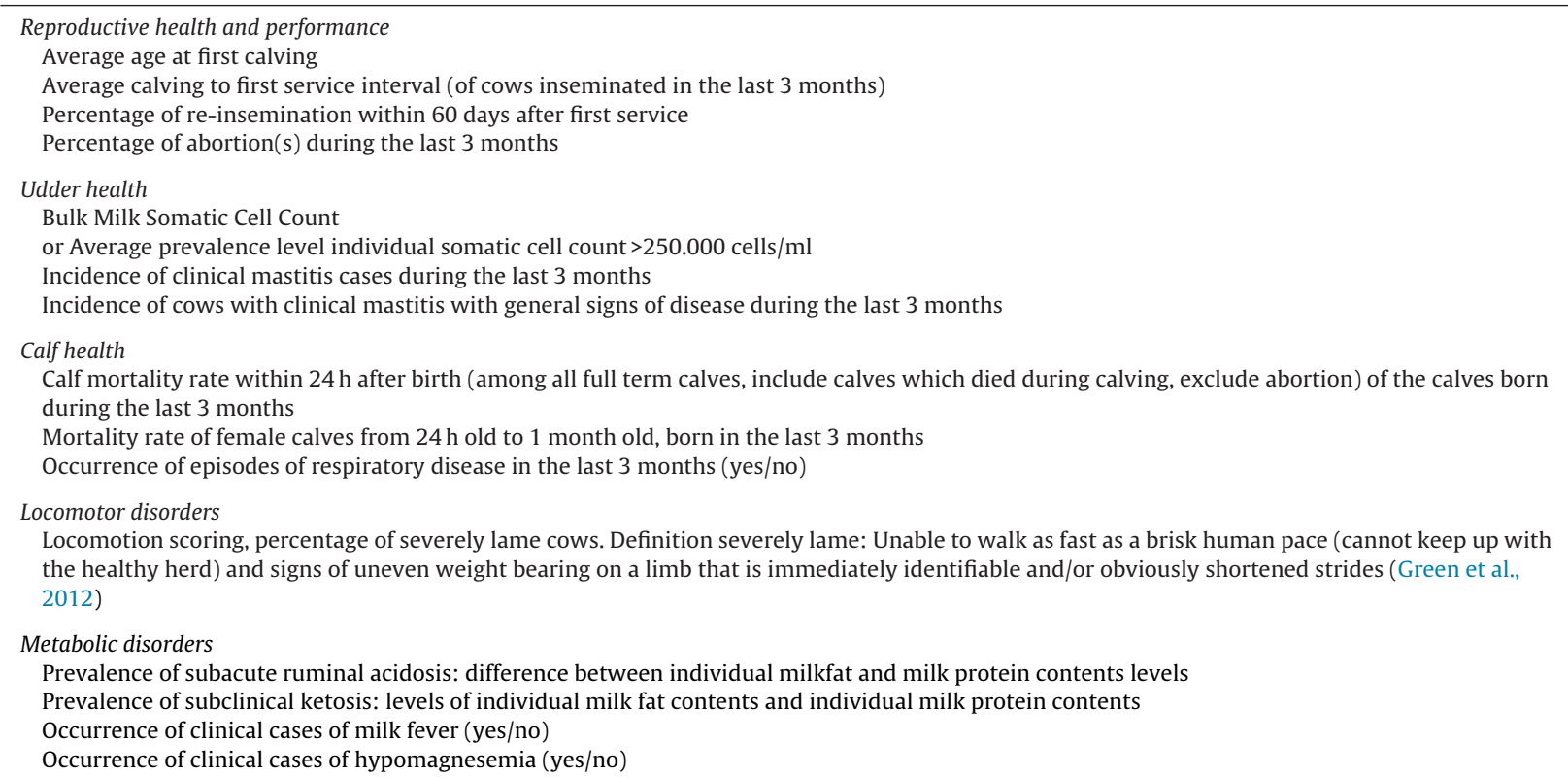

Table 2

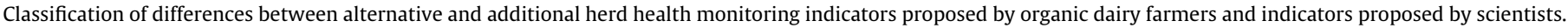

\begin{tabular}{|c|c|c|}
\hline & Characteristics of the indicators & $\begin{array}{l}\text { Examples of indicators proposed by farmers compared to the indicators } \\
\text { proposed by scientists }\end{array}$ \\
\hline A & Timing of the indicator changed & Age of heifers at start of breeding, instead of age at first calving. \\
\hline B & Animal-based observation instead of the use of data-based observations & $\begin{array}{l}>20 \% \text { of the cows in early lactation ( } 0-90 \text { days) with a strong body condition } \\
\text { loss, rather than using an indicator based on milk fat and milk protein contents }\end{array}$ \\
\hline C & Indicator takes an additional criteria into account & $\begin{array}{l}\text { Number of cows with an interval calving-first service of }>120 \text { days and a milk } \\
\text { production of } \leq 20 \mathrm{~kg} \text { per day }\end{array}$ \\
\hline $\mathrm{D}$ & Indicator for monitoring of aberrant situations & $\begin{array}{l}\text { Percentage of cows with } \geq 3 \text { artificial inseminations, rather than percentage of } \\
\text { re-insemination within } 60 \text { days after first service }\end{array}$ \\
\hline $\mathrm{E}$ & More overall indicator of the health problem under investigation & $\begin{array}{l}\text { Percentage of cows culled with infertility as the culling reason, rather than } \\
\text { percentage of cows re-inseminated within } 60 \text { days after first service }\end{array}$ \\
\hline $\mathrm{F}$ & Period at risk is different in the definition of the indicator & $\begin{array}{l}\text { Calf mortality from } 1 \text { day old to weaning (weaning at } 4 \text { months) rather than } \\
\text { mortality rate of female calves from } 1 \text { to } 30 \text { days }\end{array}$ \\
\hline G & Indicator targets a different sub-group of animals & $\begin{array}{l}\text { Percentage of primiparous cows with an individual somatic cell count of } \\
>300.000 \text { cells } / \mathrm{ml} \text { at the first milk recording after calving, rather than } \\
\text { prevalence of cows in the herd }>300.000 \text { cells } / \mathrm{ml}\end{array}$ \\
\hline $\mathrm{H}$ & $\begin{array}{l}\text { Difference due to definition of the specific cause of the health problem in } \\
\text { the definition of the indicator }\end{array}$ & $\begin{array}{l}\text { Number of cases of neonatal diarrhoea causing mortality, rather than } \\
\text { mortality rate of female calves from 1-30 days }\end{array}$ \\
\hline I & $\begin{array}{l}\text { Indicator to monitor a specific health problem which was not included in } \\
\text { the proposed list of indicators }\end{array}$ & Number of cases of endometritis (additional indicator) \\
\hline $\mathrm{J}$ & Indicator intended to further diagnose an identified problem & $\begin{array}{l}\text { Write down the types of lesions that are found during hoof trimming } \\
\text { (additional indicator) }\end{array}$ \\
\hline K & $\begin{array}{l}\text { Indicator that takes into account the farmer's herd health management } \\
\text { practices }\end{array}$ & $\begin{array}{l}\text { Percentage of cows not pregnant of those that are inseminated and checked } \\
\text { using ultrasound for gestation, rather than percentage of cows re-inseminated } \\
\text { within } 60 \text { days after first service }\end{array}$ \\
\hline $\mathrm{L}$ & Indicator to monitor the effect of a new practice on herd health & $\begin{array}{l}\text { Evaluate the effect of preventive claw trimming on the incidence of lameness } \\
\text { prior to previous year (additional indicator) }\end{array}$ \\
\hline M & $\begin{array}{l}\text { Indicator part of overview indicators of the Swedish 'Animal Welfare } \\
\text { Signals' tool }\end{array}$ & $\begin{array}{l}\text { See Appendix I for the list of overview indicators from the 'Animal Welfare } \\
\text { Signals' tool }\end{array}$ \\
\hline
\end{tabular}

\section{Results}

\subsection{Farmers' choices of animal health advisors and existing monitoring activities on the farms}

The participating farmers chose most often their private veterinary practitioner as the person to implement the monitoring plan (Table 3). In some cases, they chose advisors from the regional Chamber of Agriculture (France only) or from a local milk recording company or dairy. The reasons behind the farmers' choice of advisor were not recorded. In France, monitoring activities were already in place on 5 of the 20 farms. This included at a minimum the monitoring of herd reproductive health and performance, but never included calf health. In France, all five health topics were never monitored simultaneously. In contrast, only three Swedish farms had no monitoring activities at all. Of the 17 farms with monitoring activities, 13 farmers considered that they had monitoring activities on all five health topics.

\subsection{Results of the analysis of indicators used in farmers' herd health monitoring plans}

\subsubsection{Number of herd health indicators per health topic}

After discussing the prototype, nearly all of the farmers agreed to monitor the five health topics, including farmers whose monitoring activities prior to the study had been minimal to non-existent 
Table 3

Herd characteristics, results of farmers' choices of animal health advisors and pre-existing monitoring activities on organic dairy farms in France and Sweden.

\begin{tabular}{|c|c|c|}
\hline & \multicolumn{2}{|l|}{ Country } \\
\hline & France $(n=20)$ & Sweden $(n=20)$ \\
\hline \multicolumn{3}{|l|}{ Herd characteristics } \\
\hline Average number of lactating cows & $54(\min 18 ; \max 82)$ & $86(\min 35 ; \max 403)$ \\
\hline Average amount of milk sold per year $(\mathrm{kg})$ per cow & $5858(\min 4500 ; \max 7900)$ & $7169(\min 6960 ; \max 9400)$ \\
\hline \multicolumn{3}{|l|}{ Type of animal health advisor chosen by the farmer } \\
\hline Veterinarian & Private veterinary practitioners $(n=13)$ & $\begin{array}{l}\text { Private and district veterinary practitioners with } \\
\text { additional education in advisory services regarding } \\
\text { preventive herd health management }(n=18)\end{array}$ \\
\hline Other type of advisor & $\begin{array}{l}\text { Advisor of the regional Chamber of Agriculture on } \\
\text { organic farming }(n=4) \text {, advisor regional milk recording } \\
\text { services }(n=2) \text {, advisor milk factory }(n=1)\end{array}$ & Advisor Swedish milk recording services $(n=2)$ \\
\hline \multicolumn{3}{|l|}{ Existing herd health monitoring activities on the farm } \\
\hline None & $\mathrm{n}=15$ & $\mathrm{n}=3$ \\
\hline Yes, on one health topic & monitoring reproduction only $(n=2)$ & monitoring udder health only $(n=4)$ \\
\hline Yes, on more than 1 topic & $\mathrm{n}=3$ & $\mathrm{n}=0$ \\
\hline Yes, on all topics & $\mathrm{n}=0$ & $\mathrm{n}=13$ \\
\hline
\end{tabular}

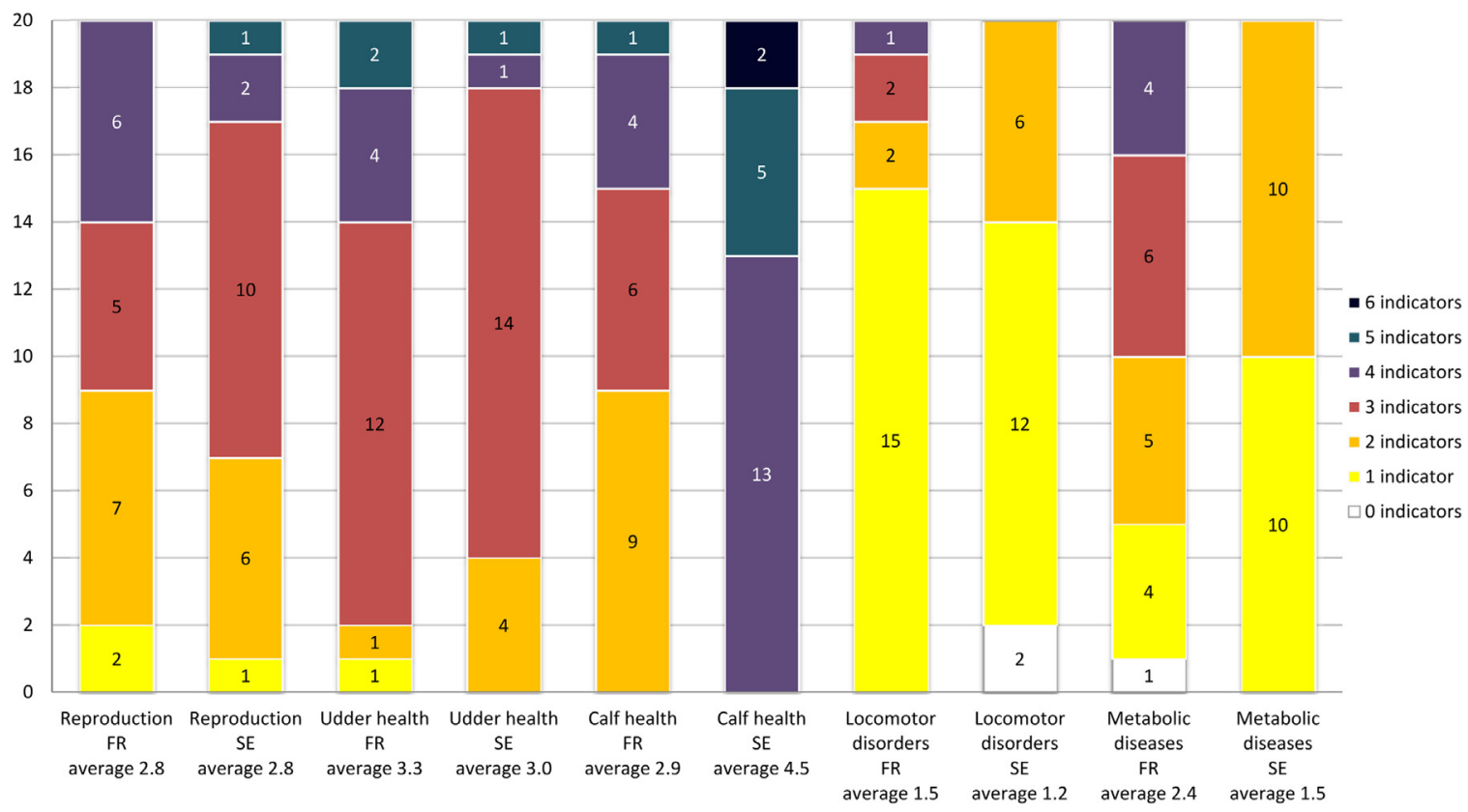

Fig. 1. Number of monitoring indicators chosen by organic dairy farmers per health topic in France (FR) and Sweden (SE).

(Fig. 1). The only exceptions were two Swedish farmers who chose not to monitor locomotor disorders and one French farmer who did not adopt an indicator for metabolic disorders. French farmers generally used a higher number of indicators than Swedish farmers except for two topics, calf health and reproductive health and performance. In the case of calf health monitoring, there was a distinct difference in the average number of indicators used between countries; Swedish farmers used 4-6 indicators (average of 4.5 indicators), whereas French farmers used 2-5 indicators (average of 2.9 indicators). For monitoring reproductive health and performance, farmers from both countries used an average of 2.8 indicators. In both countries, the lowest average number of indicators was used for monitoring locomotor disorders, with farmers most often using only one indicator.

\subsubsection{Description of the herd health indicators proposed by scientists that were retained by farmers}

Of the indicators proposed by scientists, 'mean age at first calving', 'bulk milk somatic cell count' and 'occurrence of an episode of respiratory disease (calves) in the last three months' were the most accepted indicators in both France and Sweden (Table 4). The least accepted indicators, and for which no alternative indicators were proposed, were the percentage of cows with clinical mastitis that showed general signs of disease', 'the percentage of abortions per year' and 'the occurrence of grass tetany'. The indicator 'locomotion scoring, percentage of severely lame cows' was rejected by all of the farmers but replaced by at least one alternative indicator on all 20 farms in France and 18 out of 20 farms in Sweden. Even though the number of different alternative and additional indicators was lower in Sweden, in both countries the combination of indicators adopted was unique to each farm (data not shown). Furthermore, no farmer in either country accepted the combination of indicators exactly as they were proposed by scientists.

\subsubsection{Comparison of alternative and additional indicators proposed by farmers to those proposed by scientists}

Swedish dairy farmers in many cases proposed to use indicators from the 'Animal Welfare Signals' tool as alternative indicators, but 
Table 4

Results of organic dairy farmers reactions to the indicators proposed by scientists on 20 farms in France and 20 farms in Sweden.

\begin{tabular}{|c|c|c|c|c|c|c|c|c|}
\hline \multirow[t]{2}{*}{ Indicators proposed by scientists } & \multicolumn{2}{|c|}{$\begin{array}{l}\text { Number of farms } \\
\text { where indicator } \\
\text { was accepted }\end{array}$} & \multicolumn{2}{|c|}{$\begin{array}{l}\text { Number of farms } \\
\text { where atleast } 1 \\
\text { alternative } \\
\text { indicators was } \\
\text { chosen }\end{array}$} & \multicolumn{2}{|c|}{$\begin{array}{l}\text { Number of farms } \\
\text { where no indicator } \\
\text { was chosen }\end{array}$} & \multicolumn{2}{|c|}{$\begin{array}{l}\text { Number of } \\
\text { different } \\
\text { alternative } \\
\text { indicators chosen }\end{array}$} \\
\hline & FR & SE & FR & SE & FR & SE & FR & SE \\
\hline \multicolumn{9}{|l|}{ Reproductive health and performance } \\
\hline Mean age at first calving ${ }^{\mathrm{a}}$ & 11 & 18 & 4 & 2 & 5 & 1 & 6 & 2 \\
\hline $\begin{array}{l}\text { Average calving to first service interval (of cows inseminated } \\
\text { in the last } 3 \text { months) }\end{array}$ & 10 & 2 & 5 & 0 & 5 & 17 & 3 & $\mathrm{~N} / \mathrm{A}$ \\
\hline $\begin{array}{l}\text { Percentage of re-insemination within } 60 \text { days60 days after 1st } \\
\text { service }\end{array}$ & 2 & 0 & 19 & 9 & 0 & 11 & 8 & 2 \\
\hline Percentage of abortion(s) during the last 3 months & 9 & 2 & 0 & 0 & 11 & 18 & $\mathrm{~N} / \mathrm{A}$ & $\mathrm{N} / \mathrm{A}$ \\
\hline \multicolumn{9}{|l|}{ Udder health } \\
\hline Bulk Milk Somatic Cell Count ${ }^{1}$ & 15 & 20 & 2 & 0 & 3 & 0 & 1 & 0 \\
\hline or Average prevalence level iSCC $>250.000$ cells $/ \mathrm{ml}$ & 15 & 0 & 5 & 16 & 3 & 4 & 5 & 3 \\
\hline Incidence of clinical mastitis cases during the last 3 months & 12 & 0 & 6 & 20 & 2 & 0 & 4 & 1 \\
\hline $\begin{array}{l}\text { Incidence of cows with clinical mastitis with general signs of } \\
\text { disease during the last } 3 \text { months }\end{array}$ & 2 & 0 & 0 & 0 & 17 & 20 & $\mathrm{~N} / \mathrm{A}$ & $\mathrm{N} / \mathrm{A}$ \\
\hline \multicolumn{9}{|l|}{ Calf health } \\
\hline $\begin{array}{l}\text { Calf mortality rate within } 24 \mathrm{~h} \text { after birth (among all full term } \\
\text { calves, include calves which died during calving, exclude } \\
\text { abortion) of the calves born during the last } 3 \text { months }\end{array}$ & 7 & 20 & 2 & 0 & 11 & 0 & 2 & $\mathrm{~N} / \mathrm{A}$ \\
\hline $\begin{array}{l}\text { Mortality rate of female calves from } 24 \mathrm{~h} \text { old to } 1 \text { month old, } \\
\text { born in the last } 3 \text { months }\end{array}$ & 2 & 0 & 11 & 20 & 7 & 0 & 7 & 1 \\
\hline $\begin{array}{l}\text { Occurrence of episodes of respiratory disease in the last } 3 \\
\text { months (yes/no) }\end{array}$ & 12 & 20 & 1 & 0 & 7 & 0 & 1 & $\mathrm{~N} / \mathrm{A}$ \\
\hline \multicolumn{9}{|l|}{ Locomotor disorders } \\
\hline Locomotion scoring, percentage of the herd severely lame & 0 & 0 & 20 & 18 & 0 & 2 & 13 & 7 \\
\hline \multicolumn{9}{|l|}{ Metabolic diseases } \\
\hline $\begin{array}{l}\text { Prevalence of subacute ruminal acidosis: difference between } \\
\text { individual milkfat and milk protein contents levels }\end{array}$ & 3 & 0 & 6 & 10 & 11 & 10 & 5 & 1 \\
\hline $\begin{array}{l}\text { Prevalence of subclinical ketosis: levels of individual milk fat } \\
\text { contents and individual milk protein contents }\end{array}$ & 3 & 0 & 10 & 1 & 7 & 10 & 10 & 1 \\
\hline Occurrence of clinical cases of milk fever (yes/no) & 16 & 0 & 1 & 20 & 3 & 0 & 1 & 1 \\
\hline Occurrence of clinical cases of hypomagnesemia (yes/no) & 1 & 0 & 0 & 0 & 19 & 20 & $\mathrm{~N} / \mathrm{A}$ & $\mathrm{N} / \mathrm{A}$ \\
\hline
\end{tabular}

FR = France; $S E$ = Sweden; N/A = not applicable; iSCC = individual Somatic Cell Count.

a Part of the 'overview' indicators of the Swedish 'Animal Welfare Signals' tool (Appendix I).

not all of these indicators were used and some were used more frequently than others (Tables 5 and 6).

All but one of the proposed indicators for monitoring calf health (Table 5) has at least one characteristic that suggests that farmers were focused on specific health disorders and on the specificities of disease patterns on their farm. The indicators proposed by farmers aim to monitor a specific health disorder (I, Table 2), sometimes include a cause of disease $(\mathrm{H})$, and can be specific to a group of animals at risk $(G)$ and/or a period at risk $(F)$.

A common feature of the proposed reproductive health and performance indicators (Table 6) was that many of them seem to facilitate farmers' decision making by helping to identify aberrant situations (D). An example of this is the indicator, 'Percentage of heifers that have not started reproduction and that are older than 17 months old'. Another common feature is a difference in the timing involved (A) compared to the initially proposed indicator. This results in farms sometimes having an earlier indicator, for example in the monitoring of the start of the breeding period of heifers. More often, however, the change resulted in the indicator being measured at a later point in time than that proposed by scientists, especially for the monitoring of the outcomes of insemination.

Like the proposed indicators for calf health, most of the additional indicators proposed for reproductive health and performances showed that farmers were interested in monitoring specific health problems and disease patterns.

\subsection{Analysis of the discussions on herd health monitoring indicators between farmers and advisors in France} 3.3.1. Farmers' reasoning for refusing to monitor certain areas
regarding calf health and reproductive health and performance

Some farmers did not accept the proposed indicators and did not propose any alternatives. Different reasons were evoked by farmers to explain why they do not want to monitor a specific area.

Certain farmers thought that the health problem did not occur on their farm, or occurred sometimes but they did not consider it to be a problem.

Farmer 1: Well okay, this one [referring to the indicator for calf mortality in the $24 \mathrm{~h}$ after birth] we can leave it out. We don't have problems at calving.

Researcher: So you don't have problems in the first $24 \mathrm{~h}$ ?

Farmer 1: Anyway, in the case when a calf is born and the calf is dead, I arrive and that is it! Why is it dead, we do not know. So yes, we do have some mortality but I would say it is the normal 2 percent mortality at birth.

Furthermore, in some cases the farmer believed that the situation was not likely to change and therefore not worthwhile to monitor. Farmers sometimes reached the same conclusion when they felt unable to do something to improve the health situation, or when farmer interference was not beneficial. 
Table 5

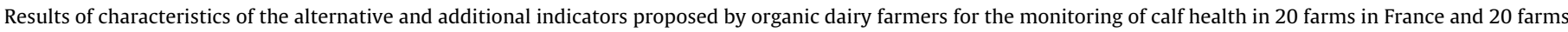
in Sweden.

\begin{tabular}{|c|c|c|}
\hline Country & Indicators proposed by farmers & Characteristics alternative indicators ${ }^{a}$ \\
\hline \multicolumn{3}{|c|}{ Alternative indicators for 'Mortality within $24 \mathrm{~h}$ after birth' } \\
\hline FR & Calf mortality at birth $(n=1)$ & $\mathrm{F}$ \\
\hline FR & Calf mortality within the $12 \mathrm{~h}$ after birth $(\mathrm{n}=1)$ & $\mathrm{F}$ \\
\hline \multicolumn{3}{|c|}{ Alternative indicators for 'Mortality rate of female calves from $24 \mathrm{~h}$ old to $1 \mathrm{month}$ old' } \\
\hline FR & $\begin{array}{l}\text { Calf mortality female calves between } 0 \text { days of age and } 1 \text { month old, cases that } \\
\text { cannot be explained excluding mortality due to calving difficulties }(n=1)\end{array}$ & $\mathrm{F}, \mathrm{H}$ \\
\hline FR & $\begin{array}{l}\text { Calf mortality (male and female calves) between } 1 \text { day of age and } 1 \text { month old } \\
(n=4)\end{array}$ & G \\
\hline FR & Calf mortality (male and female) from $12 \mathrm{~h}$ after birth on $(\mathrm{n}=1)$ & $\mathrm{F}, \mathrm{G}$ \\
\hline FR & Calf mortality (male and female) after $24 \mathrm{~h}(\mathrm{n}=1)$ & $\mathrm{F}, \mathrm{G}$ \\
\hline FR & Calf mortality (male and female) from 1 day old to weaning $(n=2)$ & $\mathrm{F}, \mathrm{G}$ \\
\hline FR & Calf mortality (male and female) due to diarrhoea 3 weeks after weaning $(n=1)$ & $\mathrm{F}, \mathrm{G}, \mathrm{H}$ \\
\hline SE & Mortality rate female calves $0-60$ days $(n=20)$ & $\mathrm{F}, \mathrm{M}$ \\
\hline \multicolumn{3}{|c|}{ Alternative indicators for 'Respiratory disease' } \\
\hline FR & Occurrence of an episode of respiratory disease with calves having fever ( $n=1)$ & $\mathrm{C}$ \\
\hline \multicolumn{3}{|c|}{ Additional indicators } \\
\hline FR & Percentage of calves with an umbilical infection $(n=3)$ & I \\
\hline FR & $\begin{array}{l}\text { Cases of neonatal diarrhoea (mainly alimentary causes) without cure in } 48 \mathrm{~h} \\
(\mathrm{n}=1)\end{array}$ & $\mathrm{G}, \mathrm{H}, \mathrm{I}$ \\
\hline $\mathrm{FR} / \mathrm{SE}$ & Percentage of calves with diarrhoea (FR $n=6, S E n=20$ ) & I \\
\hline FR & Percentage of heifer calves with diarrhoea $(n=1)$ & G, I \\
\hline FR & Number of cases of diarrhoea in calves that are less than 1 month old $(n=2)$ & $\mathrm{F}, \mathrm{I}$ \\
\hline FR & Diarrhoea morbidity female calves $0-3$ months old $(n=1)$ & $\mathrm{F}, \mathrm{G}, \mathrm{I}$ \\
\hline FR & Number of cases of diarrhoea 3 weeks after weaning $(n=1)$ & $\mathrm{F}, \mathrm{I}$ \\
\hline FR & Number of cases of diarrhoea of calves that are more than 1 month old $(n=1)$ & $\mathrm{F}, \mathrm{I}$ \\
\hline FR & $\begin{array}{l}\text { Occurrence of an episode of health problems in the herd (respiratory, } \\
\text { ringworm, etc.) }(n=2)\end{array}$ & $\mathrm{E}, \mathrm{I}$ \\
\hline FR & Percentage of stillbirths $(n=1)$ & I \\
\hline SE & Percentage of calves with impaired growth $(n=1)$ & $\mathrm{B}, \mathrm{E}$ \\
\hline SE & Mortality rate female calves from 2 months- 6 months old $(n=6)$ & $\mathrm{F}, \mathrm{I}, \mathrm{M}$ \\
\hline SE & Mortality rate female calves from 6 months- 15 months old $(n=2)$ & $\mathrm{F}, \mathrm{I}, \mathrm{M}$ \\
\hline
\end{tabular}

a For definitions see Table 2.

Table 6

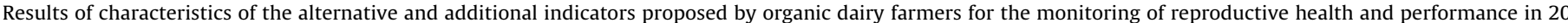
farms in France and 20 farms in Sweden.

\begin{tabular}{|c|c|c|}
\hline Country & Indicators proposed by farmers & Characteristics alternative indicators \\
\hline \multicolumn{3}{|c|}{ Alternative indicators for 'average age at first calving' } \\
\hline FR & Age at start of reproduction $(n=2)$, average age heifers at fecund insemination $(n=1)$ & A \\
\hline SE & Percentage of heifers that have not started reproduction and that are older than 17 months old $(n=1)$ & A, D, M \\
\hline FR/SE & Average success rate at first service in heifers (FR $n=2, S E n=1)$ & $\mathrm{A}, \mathrm{H}$ \\
\hline FR & Success rate of the first and second artificial insemination combined in heifers $(n=1)$ & A, $\mathrm{H}$ \\
\hline FR & Average number of artificial inseminations per pregnancy in heifers $(n=1)$ & A, $\mathrm{H}$ \\
\hline FR & Occurrence of heifers calving in May and/or June $(n=1)$ & A, D \\
\hline \multicolumn{3}{|c|}{ Alternative indicators for 'average interval calving-1st service' } \\
\hline FR & Percentage of cows with a prolonged interval calving - first heat $(n=3)$ & $\mathrm{A}, \mathrm{D}, \mathrm{F}$ \\
\hline FR & Percentage of cows with a prolonged interval calving - first service $(n=2)$ & A, D \\
\hline FR & Number of cows with an interval calving - first service of $>120$ days and a milk production of $<20 \mathrm{~kg}$ per day $(n=1)$ & C, D \\
\hline \multicolumn{3}{|c|}{ Alternative indicators for 'average percentage of cows re-inseminated after 1st service' } \\
\hline FR & Average success rate first service $(n=7)$ & A \\
\hline FR & Success rate of the first and second artificial insemination combined $(n=2)$ & $\mathrm{A}, \mathrm{E}$ \\
\hline FR & Percentage of cows not pregnant of those that are inseminated and checked using ultrasound for gestation $(n=1)$ & $\mathrm{K}$ \\
\hline FR & Cow that returned into heat after third insemination $(n=4)$ & A,D \\
\hline FR & Individual cow that returned into heat $>120-150$ days after insemination $(n=1)$ & A, D \\
\hline FR/SE & Average interval calving- last insemination ( FR $n=1, S E n=1$ ) & A, F, M \\
\hline $\mathrm{FR} / \mathrm{SE}$ & Average number of inseminations per pregnancy $(\mathrm{FR} n=4, \mathrm{SE} n=9)$ & A \\
\hline FR & Percentage of cows culled with infertility as the culling reason $(n=4)$ & A, E, M \\
\hline \multicolumn{3}{|c|}{ No alternative indicators were proposed for the indicator 'percentage of abortions' } \\
\hline \multicolumn{3}{|c|}{ Additional indicators } \\
\hline FR & Measuring the effect of a new monitoring system for detecting cows in heat $(n=1)$ & $\mathrm{L}$ \\
\hline SE & Monitoring the occurrence of reproduction problems $(n=2)$ & I \\
\hline FR & Percentage of cows treated for metritis with antibiotics $(n=1)$ & C, G, I \\
\hline FR & Occurrence of cases of metritis $(n=1)$ & I \\
\hline FR/SE & Average calving interval $(\mathrm{FR} n=1, \mathrm{SE} n=16)$ & $\mathrm{E}, \mathrm{M}$ \\
\hline SE & Percentage of calvings with calving difficulties $(n=2)$ & $\mathrm{I}, \mathrm{M}$ \\
\hline
\end{tabular}

\footnotetext{
a For definitions see Table 2.
} 
Farmer 2: Well, I do have some calf mortality. But often...I don't have the impression that we can do something about it...I have decided not to assist cows at calving as much anymore since the day. . . Before, I assisted at almost every calving and one day when we had to go somewhere there was a cow that was supposed to calf, but who didn't, so I got the calf out but I watched the calf die and several days later the cow died too. That was the trigger. I said 'now I leave the cows calving by themselves'. And they are not doing badly. They are doing better in general.

With regard to monitoring reproductive health and performance, a farmer's management objectives could influence the decision to reject monitoring activities in certain areas. This decision was influenced, for example, by an objective for seasonal calving, the feeding system on the farm, or the farmer' personal planning.

Farmer 9: Age at first calving is always around 30-33 months on our farm, because we have seasonal calving at a certain period during the year, so it would be at 2 or 3 years. So, I don't want it to be at 2 years, because it would force us to have a stricter heifer management ... They would need concentrates, and it is more difficult to maintain the pasturing schedule the way we do it now. So we forget that, as an indicator "age at first calving".

\subsubsection{Farmers' reasoning in their choice of alternative and} additional indicators for monitoring calf health

The analysis of the discussions on alternative indicators showed that farmers used their knowledge of disease patterns which were specific to their farms when they changed the proposed indicators.

Advisor 11: What do we take [as indicator for the monitoring of calf health]? Do we keep the mortality rate? Do we keep this criterion? I don't really know what else to propose. Farmer 11: To me, mortality rate doesn't seem to be enough. I have a mortality rate that is correct for sure, but I have a lot of sick calves.

Farmer 3: We keep the male calves, we fatten them. It is a way for us to improve the financial worth of the calves. And we have many male calves. Advisor 3: So in fact you would count all calves, male and female, when monitoring? Farmer 3: Yes, all the calves that we raise. The male calves leave at 4 months for slaughter. And actually it is often the male calves that have small health problems.

Additional indicators were proposed as well and were either related to a specific animal health problem on the farm which was bothering the farmer or problems in the (recent) history of the farm.

\subsubsection{Farmers' reasoning behind their choice of alternative and additional indicators for monitoring reproductive health and performance}

When farmers choose to adapt indicators for monitoring reproductive health and performance, this can be related to the strategic choices made on the farm, such as the type of farm system (organic), specific practices, and the farmer's objectives. Using natural service rather than artificial insemination is a practice that is expected to occur more frequently in organic production systems compared to conventional ones.

Farmer 6: Indeed, when I look at the interval calving to first service I also look at the milk production level of the cow. This morning I inseminated a cow in her first lactation that produces $22 \mathrm{~kg}$. I said to myself 'it is ok, she is at a little bit less than 60 days in lactation, and her first heat was perfect, so I inseminated her'. But if it had have been a cow that produces on average 8000 per lactation and she is still at $35 \mathrm{~kg}$ of milk per day I would not inseminate her even though she started her lactation at the same time. The idea behind this is that we have cows here that produce a lot of milk, but who suffer negative energy balances due to the fact that they are in an organic system. So we have understood quickly that there is no point in inseminating the high producing cows at sixty days in lactation, it is not successful.

Furthermore, indicators might also be used to identify aberrant cases for which the farmer has to make a decision.

Farmer 10: The percentage of cows re-inseminated in the 60 days after artificial insemination. Advisor 10: Usually it is a maximum of 3 artificial inseminations that is used, isn't it? Farmer 10: Yes, yes. The cases with 4 inseminations, if you have one or two cases per year. ...3 inseminations, that is an indicator to decide whether we want to keep the cow or not.

In addition, ergonomic factors were taken into account by farmers. Some indicators were changed because certain data were unavailable on the farm, rendering it impossible to calculate the indicators, or because the farmer was accustomed to using another indicator.

Additional indicators were chosen when a specific health topic identified by the farmer as a problem was not addressed in the list of proposed indicators, such as the number of cows treated for metritis with antibiotics. Certain indicators also were chosen due to their economic importance to the farmer.

Farmer 14: I think that the calving interval is quite good as an indicator. But maybe that is because we. ..well, for us, economically it is the indicator which interests us most because, on average, our cows do not have a high production level.

\section{Discussion}

The results of this study show that following the use of a participatory approach, organic dairy farmers intended to monitor multiple animal health topics simultaneously. Farmers planned to do so even on farms where no monitoring activities were present prior to the start of the study. Except for two Swedish farmers who chose not to monitor locomotor disorders and one French farmer who chose not to monitor metabolic disorders, all of the other farmers planned to monitor the five health topics.

Another significant result was that all of the farmers made use of the possibility to adapt the indicators proposed by the scientists, and this resulted in 40 unique herd health monitoring plans. The adaptations made to the indicators were very farm-specific. It therefore appears crucial to take into account farmers' experiences when designing farm-specific indicators, a task enabled by the use of a participatory approach. This is in line with the work of Mathieu et al. (2004), in which they state that scientists should aim to design decision support models which are based on sound biotechnical references and pertinent to farmers. However, scientists should not aim to provide each individual farmer with a perfect model because scientists will never be able to fully capture how farmers consider the use of the tool in question. The argument for tools which can be adapted to each farmer's use is supported even more strongly by the results from Sweden. In this country, where herd health indicators are used on a large share of farms and are provided with reference values, farmers also chose unique sets of indicators for herd health monitoring on their farms. Another striking example is the fact that not one farmer adopted the indicator proposed by scientists for locomotor disorders, but with the exception of two Swedish farmers, all agreed to monitor locomotor disorders after the indicator was adapted. The use of an adaptable tool thus seems pertinent. Describing the most frequently accepted indicators and using them for the design of general monitoring plans consequently appears irrelevant and suggests that the design of 'one-size fits-all' tools should be abandoned. 
Country differences were found and were likely due to the different contexts. It is not likely that the use of two different interviewers had an important effect on the outcome, since the study was performed in a standardized way across countries and the interviewers played a facilitating rather than an expert role. The differences between countries might have different reasons. Firstly, the country difference in terms of the advisory services available at the start of the study may be one reason. Despite the low number of participating farms, the results regarding the existing monitoring activities indicate indeed that veterinary herd health management programs are not common on organic dairy farms in France. In Sweden, a contrasting situation exists, one which is closer to that of The Netherlands, for example (Derks et al., 2013a). This country difference might be related to the fact that in Sweden, the role of a veterinarian on organic dairy farms and in disease prevention strategies is defined in organic production regulations. We know that local or national conditions are not always comparable and might affect the implementation of management measures (Sundrum, 2001). Secondly, we might also assume that the widespread use of the 'Animal Welfare Signal' tool plays a role. For example, the fact that the alternative and additional indicators chosen by Swedish farmers were in general more overall indicators can probably be at least partially explained by the fact that the farmers are familiar with these indicators and their reference values through their use of the tool. The exception to this was the monitoring of calf health, for which Swedish farmers used a high number of indicators. A possible explanation for this is the fact that the advisory services related to this issue are comparatively less developed than those dedicated to other health topics in Sweden. It would be interesting to study the influence of such a widely implemented tool on the animal health and welfare situation and its use by farmers in order to further understand the effect of such a large diffusion and availability of herd health data.

The results of this study seem to indicate that farmers use indicators differently than scientists. Health indicators have often been proposed to be used for benchmarking purposes (Tremetsberger and Winckler, 2015). These can be used by farmers, advisors, decision-makers and scientists for between-herd comparisons. In general, farmers have a different point of view of technical tools than scientists due to the fact that they live in different social environments and work on a regular basis with these tools. To be able to understand farmers' practices, scientists have to understand the perceptions of farmers which explain and justify their actions. When aiming to design relevant decision support tools for farmers, it is thus essential to understand their vision and goals and to have an understanding of the indicators that motivate their practices (Mathieu et al., 2004). Little research has been done on indicators that farmers use to monitor production diseases and their validity for early disease recognition and prevention. Scientists, in general, analyze data from many herds, for between herd comparison and sometimes use complex conceptual frameworks to make sense of this data. The indicators proposed by scientists in this study were overall indicators, e.g. aiming to monitor mortality rates at different ages without including details such as cause of death. Farmers, on the opposite, use data for decision making on a daily basis. They have more data than scientists on events that are not recorded in databases. They have considerable information about what happens in their own herds but much less about what happens in other herds. From the analysis of the interviews, it became evident that farmers adapt the indicators to specific health problems occurring on their farms, and use them to analyze whether their objectives are being reached and in their decision-making processes. Thus the indicators seem to be used for within-herd comparisons rather than for between-herd comparisons. The fact that each Swedish farmer also chose unique combinations of indicators underlines this. Nevertheless, we remain aware that the different kinds of indicators (for within-herd and between-herd comparisons) all have their own utility but have to be used in the appropriate context (daily management, benchmarking, quality assurance, research purposes).

The qualitative analysis of the discussions enabled an understanding of the meaning of herd health indicators to the farmers themselves. The analysis confirmed the function of the characteristics identified when describing the alternative and additional indicators proposed by farmers. The indicators proposed for monitoring calf health are based on farmers' knowledge of local disease patterns and a prioritisation of health problems as described above. The indicators designed for reproductive health and performance were also adapted to farmers' objectives and strategic management. In the context of the development of disease surveillance programs, integrating farmers' knowledge has proven to be of value to clarify the clinical picture and epidemiology of diseases under local conditions, to identify livestock owners' animal health priorities, and to improve the relationship between farmers and animal health professionals by respecting farmers' knowledge (Catley et al., 2012). For example, participatory disease surveillance played a major role in the eradication of rinderpest (cattle plague). Livestock owners' knowledge was crucial in the identification of the final foci of infection, the development of guidelines to control infection, and the process of certifying countries as being free of rinderpest (Jost et al., 2007). The results of our study also show that in the construction of the monitoring plan, the farmers used their farm-specific (local) knowledge to prioritize the health problems to be monitored and to design indicators which monitor the specific diseases that occur on their farm.

The participatory approach encouraged farmers and advisors to engage in a dialogue during which animal health was discussed as a component of the whole farm system. The selection of indicators proposed by scientists was not chosen to represent the gold standard for monitoring herd health. Proposing indicators was part of the participatory approach and aimed at initiating discussion on at least five topics that represent major threats for dairy cattle health and welfare. The analysis of the discussions showed that this dialogue was not only an important source of information for advisors on farmers' use of indicators, but also a means to acquire detailed knowledge on (recent) health problems on the farm, and the farmers' objectives, priorities and practices. In the past, organic dairy farmers expressed the view that veterinarians did not always respect their goals and that veterinarians did not support them in developing practices that were more in line with organic production principles (Vaarst et al., 2007, 2006). In this study, we have shown examples of situations in which specificities of the organic farming system influenced the choice of indicators. Animal health should be considered as an integral part of the farm system and farmer objectives on not only organic farms, but every farm. If advisors want to be able to contribute to farmers' animal health planning activities in general, such as in HHPM programs, they will have to adopt systemic approaches and consider herd health as a part of the farm system. They must not only have profound technical knowledge on health management, but other domains such as feeding and housing as well, and take into account the organization of the farm and the farmer's objectives when recommending practices (Brand et al., 2001; LeBlanc et al., 2006; Vaarst, 2011). Whay and Main (2010) also recognise the value of farmers' knowledge, and the importance of understanding how a specific farm functions and the reasons for which certain routines and practices have been adopted before giving advice. The discussion provoked by the participatory approach allowed advisors to obtain a view of animal health as an integral part of the farm system and the farmer's objectives. This information is crucial if advisors want to recommend practices that are accepted by farmers. The 
importance of discussion between farmers and advisors thus should be recognised.

This study did not assess the long term effectiveness of the use of farmer-designed monitoring tools on improving animal health. However, the participation of advisors is expected to minimize the probability that farmers adopt inappropriate indicators. Nevertheless, we recommend that the validity of the monitoring plans designed by farmers to be evaluated in terms of their health promotion capacities in future research. Farmers' long term compliance with monitoring activities was not assessed, but the first hurdle - engaging farmers in planning the activity - was successfully taken. Furthermore, by employing a participatory approach, known preconditions for sustainable animal health and welfare planning activities on organic dairy farms were met; e.g. farmer ownership of the process was assured, the approach stimulated dialogue between farmers and advisors, the indicators were farm-specific and included farm-specific knowledge and data. It has been recognised that stakeholders' commitment to disease surveillance and control activities can be promoted by having them participate in the prioritisation of disease problems and in the development of the activities. The co-construction experience is expected to improve trust between actors, improve compliance, and thus, in the end, result in a positive impact on animal health. Although participatory approaches have been used most often in developing countries, they can be valuable in the design of disease control activities in developed countries (Catley et al., 2012).

\section{Conclusion}

The participatory approach used led to the design of indicators that permit farmers to monitor simultaneously the major health and welfare indicators associated with production diseases in dairy cattle. Furthermore, the indicators were farm-specific, as they were adapted to the farmer's objectives, herd health situations and/or decision-making processes. Therefore, when designing decision support tools for farmers, scientists should not aim at 'one-size fits all' tools. The analysis of the discussions between farmers and advisors on the indicators revealed that scientists and farmers use herd health indicators differently. While scientists use indicators for between-herd comparisons, farmers are interested in withinherd comparisons. Moreover, the participatory approach provoked a dialogue between farmers and advisors which allowed advisors to understand animal health management as an integral part of the farm system and the farmer's objectives. This understanding is crucial for advisors aiming to contribute to animal health planning activities of all farmers.

\section{Acknowledgements}

We would like to thank all of the farmers and advisors who participated in this study for their time and efforts, the farmers' organizations for recruiting farmers, and Manon de Joybert for her organizational assistance during the study.

This work received funding from the European Union's Seventh Framework Programme for research, technological development and demonstration under grant agreement number 311824 (IMPRO), and by the Region Pays de la Loire under grant agreement number 201309596.

\section{Appendix I.: Overview of the indicators in the Swedish 'Animal Welfare Signals'-tool}

\section{Calves}

Mortality rate calves between 1-60 days

Mortality rate calves between 2-6 months

Young stock
Mortality rate young stock between 6-15 months

Percentage of heifers older than 17 months that have not started breeding

Mean age at first calving

Calving

Calf mortality rate within the 24 hours after birth

Percentage of difficult calving

Feed balance

Paralysis or cramps (includes milk fever, grass tetany)

Other feeding disorders (includes acidosis, ketosis)

Abnormal urea values

Low urea values

Diseases

Total reported cows with disease

Treatments for mastitis

Calculated Bulk milk cell count

Monitoring and care

Percentage of cows with a calving-first insemination interval of more than 70 days

Percentage of cows with an interval calving-last insemination interval

of more than 120 days

Percentage of cows culled due to fertility problems

Average calving interval

Sustainability

Percentage of claw and leg disorders

Percentage of primiparous cows culled 1-90 days after calving

Total percentage of culled cows

Percentage of unassisted death/euthanized cows

\section{References}

Anonymous, n.d. Växa Sverige [WWW Document]. URL http://www.vxa.se/ Radgivning-service/Djurhalsa/Djurvalfard8/Signaler-DJurvalfard/ (accessed 12.1.15).

Barkema, H.W., Van der Ploeg, J.D., Schukken, Y.H., Lam, T.J., Benedictus, G., Brand, A., 1999. Management style and its association with bulk milk somatic cell count and incidence rate of clinical mastitis. J. Dairy Sci. 82, 1655-1663, http:// dx.doi.org/10.3168/jds.S0022-0302(99)75394-4.

Bell, N.J., Bell, M.J., Knowles, T.G., Whay, H.R., Main, D.J., Webster, A.J.F., 2009. The development, implementation and testing of a lameness control programme based on HACCP principles and designed for heifers on dairy farms. Vet. J. 180, 178-188, http://dx.doi.org/10.1016/j.tvjl.2008.05.020.

Brand, A., Noordhuizen, J.P.T.M., Schukken, Y.H., 2001. Herd Health and Production Management in Dairy Practice, 3rd. Wageningen Pers, Wageningen

Catley, A., Alders, R.G., Wood, J.L.N., 2012. Participatory epidemiology Approaches, methods, experiences. Vet. J. 191, 151-160.

Commission, E., 2008. Commission regulation (EC) No 889/2008. Off. J. Eur. Union.

Derks, M., van Werven, T., Hogeveen, H., Kremer, W.D.J., 2013a. Veterinary herd health management programs on dairy farms in the Netherlands: use, execution, and relations to farmer characteristics. J. Dairy Sci. 96, 1623-1637, http://dx.doi.org/10.3168/jds.2012-6106.

Derks, M., van Woudenbergh, B., Boender, M., Kremer, W., van Werven, T., Hogeveen, H., 2013b. Veterinarian awareness of farmer goals and attitudes to herd health management in The Netherlands. Vet. J. 198, 224-228.

EFSA, 2009. Scientific report of EFSA prepared by the Animal Health and Animal Welfare Unit on the effects of farming systems on dairy cow welfare and disease. Annex EFSA J.

EFSA, 2012. Scientific Opinion of the Animal Health and Welfare Panel on the use of animal-based measures to assess welfare of dairy cows. EFSA J., http://dx. doi.org/10.2903/j.efsa.2012.2554.

Garforth, C., 2011. Effective communication to improve udder health: can social science help? In: Hogeveen, H., Lam, T.J.G.M. (Eds.), Udder Health and Communication. Wageningen Academic Publishers, Utrecht, The Netherlands, pp. 55-66, http://dx.doi.org/10.3920/978-90-8686-742-4.

Green, M.J., Leach, K.A., Breen, J.E., Green, L.E., Bradley, A.J., 2007. National intervention study of mastitis control in dairy herds in England and Wales. Vet. Rec. 160, 287-293.

Green, M., Bradley, A., Breen, J., Higgins, H., Hudson, C., Huxley, J., Statham, J. Green, L., Hayton, A., 2012. Dairy Herd Health, 1st ed. CAB International.

Jost, C.C., Mariner, J.C., Roeder, P.L., Sawitri, E., Macgregor-Skinner, G.J., 2007. Participatory epidemiology in disease surveillance and research. Rev. Sci. Tech. 26, 537-549.

LeBlanc, S.J., Lissemore, K.D., Kelton, D.F., Duffield, T.F., Leslie, K.E., 2006. Major advances in disease prevention in dairy cattle. J. Dairy Sci. 89, 1267-1279, http://dx.doi.org/10.3168/jds.S0022-0302(06)72195-6.

Mathieu, A., Lasseur, J., Darré, J.-P., 2004. Un projet d'agronomes: accéder aux conceptions des agriculteurs pour comprendre les pratiques. In: INRA Editions (Ed.), Le Sens Des Pratiques. Conceptions D'agriculteurs et Modèles D'agronomes, INRA, Paris, pp. 19-69.

Noordhuizen, J.P.T.M., Wentink, G.H., 2001. Developments in veterinary herd health programmes on dairy farms: a review. Vet. Q 23, 162-169. 
Noordhuizen, J., Cannas da Silva, J., Boersema, J.-S., Vieira, A., 2008. Applying HACCP-based Quality Risk Management on Dairy Farms. Wageningen Academic Publishers, Wageningen.

Sundrum, A., 2001. Organic livestock farming. Livest. Prod. Sci., http://dx.doi.org/ 10.1016/s0301-6226(00)00188-3.

The KRAV Association, 2015. Standards for KRAV-certified Production 2015 Version Uppsala, Sweden.

Tremetsberger, L., Winckler, C., 2015. Effectiveness of animal health and welfare planning in dairy herds: a review. Anim. Welf. 24, 55-67, http://dx.doi.org/10. 7120/09627286.24.1.055.

Vaarst, M., Alban, L., Mogensen, L., Thamsborg, S.M., Kristensen, E.S., 2001. Health and welfare in Danish dairy cattle in the transition to organic production: problems, priorities and perspectives. J. Agric. Environ. Eth. 14, 367-390, http://dx.doi.org/10.1023/A:1013060304868.

Vaarst, M., Bennedsgaard, T.W., Klaas, I., Nissen, T.B., Thamsborg, S.M., Østergaard, S., 2006. Development and daily management of an explicit strategy of nonuse of antimicrobial drugs in twelve Danish organic dairy herds. J. Dairy Sci. 89, 1842-1853, http://dx.doi.org/10.3168/jds.S0022-0302(06)72253-6.
Vaarst, M., Nissen, T.B., Østergaard, S., Klaas, I.C., Bennedsgaard, T.W., Christensen, J., 2007. Danish stable schools for experiential common learning in groups of organic dairy farmers. J. Dairy Sci. 90, 2543-2554, http://dx.doi.org/10.3168/ jds.2006-607.

Vaarst, M., Winckler, C., Roderick, S., Smolders, G., Ivemeyer, S., Brinkmann, J., Mejdell, C.M., Whistance, L.K., Nicholas, P., Walkenhorst, M., Leeb, C., March, S. Henriksen, B.I.F., Stöger, E., Gratzer, E., Hansen, B., Huber, J., 2011. Animal health and welfare planning in organic dairy cattle farms. Open Vet. Sci. J. 5 , 19-25.

Vaarst, M., 2011. Animal health and welfare planning in organic dairy cattle farms. Open Vet. Sci. J. 5, 19-25.

Whay, H.R., Main, D.C.J., 2010. Improving Animal Welfare: Practical Approaches for Achieving Change, in: Grandin, T. (Ed.), Improving Animal Welfare: A Practical Approach. pp. 227-251. 